\title{
Public domain as a master frame?
}

\author{
Sebastian Haunss
}

University of Bremen, SOCIUM - Research Center on Inequality and Social Policy sebastian.haunss@uni-bremen.de

DOI: http://dx.doi.org/10.5324/eip.v10i1.1969

(cc) BY This is an open access article distributed under the terms of the Creative Commons Attribution 4.0 International License, which permits unrestricted use, distribution, and reproduction in any medium, provided the original author and source are credited.

In a widely cited article Boyle suggests that a movement against the growing propertization of knowledge should develop a mobilization frame centered around the idea of the public domain. Based on an analysis of the framing strategies in the two most important protest mobilizations against extensive intellectual property rights I discuss whether and to which degree these movements did actually put the concept of the public domain at the center of their argumentation. The article uses political claims analysis and discourse analysis to show that the actual framing strategies relied on other frames. It closes with a discussion, explaining why the idea of the public domain is essentially a defensive concept with a limited potential for movements that primarily address the production of knowledge.

Keywords: Intellectual Property Rights, Public Domain, Social Movements, Knowledge Society, Discourse Analysis

In a widely cited article, James Boyle (2003) develops a powerful narrative of intellectual property rights as the "second enclosure movement". While the first enclosure movement transformed public land into private property, the second enclosure movement transforms "the intangible commons of the mind" (Boyle 2003: 37) into intellectual property. In both cases, public access is restricted by creating exclusive rights. To counter the growing propertization of knowledge, Boyle argues that the idea of the public domain has to be developed. Like the notion of "the environment" that had to be developed before it was possible to bring together nature enthusiasts, conservationists, ecologists and others in the environmental movement, "an emergent concept of the public domain could tie together the interests of groups currently engaged in individual struggles with no sense of the larger context" (Boyle 2003: 71) in the field of the politics of intellectual property (Haunss \& Shadlen 2009). Boyle thus suggests that a movement against the growing propertization of knowledge should develop a mobilization frame centered on the idea of the public domain.

More than a decade after this proposal was made, we can indeed see a revival of the ideas of the public domain and the commons. In the digital realm, Creative Commons has proven to be a veritable success story. Since December 2002, when the first Creative Commons license was issued, millions of Internet users have chosen to release their creative works (text, pictures, music, etc.) under a license that largely reverses the exclusiveness and restrictions of traditional copyrights 
(Dusollier 2006). The most recent data available shows that since then, not only the absolute number of licenses but also the license adoption rate is still growing, so that Creative Commons was able to announce at the end of 2015 that over 1 billion works have been made available under its licenses (Creative Commons 2015). And in addition to individual Internet users, governments, public administrations and scientific organizations are also releasing their data and works under a Creative Commons license. The success of the idea of a digital commons is paralleled by a growing interest for the idea of the commons in the analog world as well - especially after Elinor Ostrom received the in 2009 the Nobel Memorial Prize in Economic Sciences for her institutional economic studies on the governance of the commons (Ostrom 1990).

Has the concept of the public domain or the commons in effect become a unifying master frame (Snow \& Benford 1992: 138), bringing together various organizations and protests under a shared interpretation and with a common goal? Have these concepts played a central role in recent conflicts about intellectual property rights? Or do other frames play a more central role in uniting social movements that are addressing conflicts of the knowledge society?

To answer these questions, I will analyze the framing strategies of the opponents of strong intellectual property rights by focusing on two conflicts in the field of the politics of intellectual property: 1) the global mobilization on access to medicines, and 2) the European conflict over software patents. These two conflicts so far represent the largest mobilizations in which intellectual property rights have been politicized and which involved forms of action usually associated with social movements - most importantly large-scale public protests. Moreover, each conflict has developed a lasting impact on IP politics. For both cases, the analysis will examine whether and to what degree frames about the public domain and the commons functioned as a master frame uniting various actors' argumentations or whether the actors involved in these conflicts constructed their argumentation mainly around other frames that do not focus primarily on the propertization of immaterial goods. The goal of the article is to judge the relative importance of the ideas of the public domain and the commons in current conflicts of the knowledge society.

On the following pages I will first briefly introduce the data sources and methods used to identify the frames employed by the actors. I will then discuss the two conflicts separately, starting with the access to medicines mobilization, because it represents the broader conflict of the two. The article closes with a more general comparative discussion of the framing strategies and how they should be interpreted.

\section{Data and methods}

For the analysis of the actors' framing strategies, I draw on empirical data originally collected in a larger project about conflict in the knowledge society (Haunss 2013). More specifically, in the access to medicines conflict, the analysis is based on 30 documents published by core actors involved in the conflict. These documents were coded in a qualitative content analysis (Kelle, Prein \& Bird 1995; Titscher, Meyer, Wodak \& Vetter 2000) in which passages were identified that represent the actors' diagnostic, prognostic and motivational frames (Snow \& Benford 1988). The coding 
used the qualitative data analysis package RQDA (Huang 2010). Based on this coding, it is possible to identify the master frames of each of the two camps. I methodically followed Gerhards' and Rucht's approach to analyzing mesomobilization processes, i.e. mobilization and negotiation processes among groups mobilizing in a common campaign (Gerhards \& Rucht 1992). Similar to their study, my main interest was to identify elements of the collective action frames that help the actors of a heterogeneous network to develop a common interpretation and action strategy.

The analysis in the software patents conflict is based on a broader document corpus. Because of the more limited geographical scope of the software patents conflict, it was possible to base the analysis on the content coding of 124 newspaper articles published in quality newspapers in Germany, Great Britain, France and Poland between 1997 and 2005. ${ }^{1}$ As a first step, all articles mentioning the software patents conflict in Europe or the issue of software patents in general were selected. In these articles every instance of claims-making was coded according to a coding scheme (Haunss \& Kohlmorgen 2008) that is a further development of Koopmans' political claims analysis codebook (Koopmans 2002). A claim in this context means any demand, proposal, criticism, decision, etc. made by actors active in the respective field of conflict in the form of statements or collective mobilizations. This can be a parliamentary motion, a formal vote, a petition, a demonstration or any other act of public political intervention. For each claim, the content of the claim, the date, name and organizational affiliation of the claimant, addressees (if explicitly mentioned) and the argumentative frame were recorded. Frames in this context are the reasons that are given for a specific instance of claims-making. They are the sometimes explicit, often implicit - arguments or concepts used by the actors. To give an example: An article reports that an actor has published a press release in which he demands that the European Parliament should reject the directive, because it would disadvantage small IT companies. This article contains a claim - the press release - and a frame - "Software patents are bad because they negatively affect the competitiveness of small and medium sized enterprises". In the database this is then coded as actor X making a claim (publishing a press release), using the frame "competitiveness of SMEs". It is furthermore recorded that the frame "competitiveness of SMEs" is here used to argue against software patents in Europe. Overall, the 124 articles contained 338 claims for which a clear actor position in the conflict was given.

The original dataset covers statements from all actors present in the conflict, those in favor of stronger intellectual property rights and those struggling against far-reaching pharmaceutical patents in the developing world and against software patents in Europe. The following analysis only draws on the statements from oppositional actors, since my focus here is limited to the opponents of strong intellectual property rights.

\section{Access to medicines}

On a global level, the broadest and most prominent conflict about intellectual property rights was certainly the conflict about access to (essential) medicines. At its core it was, and still is, a conflict about the effects of patents for pharmaceutical products on access to drugs for patients living in countries of the Global South. The 
conflict was fueled, in particular, by the issue of access to HIV/AIDS medication (for a more detailed discussion, see Reis, Terto \& Pimenta 2009; 't Hoen 2009; Haunss 2013: Chapter 5).

The coordinates for this conflict were set by the dual dynamics of an accelerating rate of HIV infections in a number of developing countries in Africa, Asia and South America and a ratcheting up of IP protection that culminated in the 1995 TRIPS agreement. Medical advances have, for many patients in the Global North, converted AIDS in the $21^{\text {st }}$ century from a deadly illness to a manageable chronic disease (Osborn 2008). But for most patients in the Global South, this is not yet the case. By the end of the 1990s, about one-third of the world's population did not have access to essential medicines, and often even no access to primary health care. One reason for this is that many countries lack the necessary medical infrastructure. But even where this infrastructure exists, essential drugs are often simply unaffordable for many people in the world's poor countries. This is the epidemiological backdrop against which several NGOs started a campaign for access to essential medicines in the late 1990s.

The second thread of this conflict goes back to the Uruguay Round of world trade negotiations. The Uruguay Round of multilateral trade negotiations started in 1986 and ended nine years later with the transformation of the General Agreement on Tariffs and Trade (GATT) into the World Trade Organization (WTO). One part of the negotiations was a multilateral agreement on Trade-Related Aspects of Intellectual Property Rights (TRIPS) that was included in the final WTO treaty and went into force on 1 January 1995. TRIPS marked an important change in international IP politics, as it shifted responsibility for IP issues from WIPO and other UN agencies to the WTO. All TRIPS member states are required to guarantee in their national legislation a number of minimum standards of IP protection, among them a minimum copyright term of 50 years after the death of the author, a minimum patent term of 20 years (Art. 12) and a clause that patents must be granted "in all fields of technology" (Art. 27-33) - including pharmaceutical products. For many countries this meant far-reaching changes to their patent legislations, and in the field of pharmaceutical patents it foreclosed the option of process patents that some developing countries, notably India, had chosen until then, and which had allowed them to produce cheap generic versions of brand name medicines. Because the actual synthetization of a medicine's active ingredient is usually not overly complex in the pharmaceutical production process, process patents allow firms to analyze the chemical composition of pharmaceuticals available on the market, and then develop an alternative process ${ }^{2}$ to produce a drug with the same chemical structure. TRIPS eliminated this option. Instead, all countries are now required to introduce product patents in all fields of technology, including pharmaceuticals, and to guarantee a 20 -year minimum patent term. This is the global IP backdrop of the access to essential medicines campaign.

The goal of the access to medicines campaign was, and still is, to provide patients in the Global South with the drugs they need to fight the most dangerous illnesses, above all HIV/AIDS. The access to medicines campaign started as an NGO mobilization in 1996 with a meeting of several health NGOs in Bielefeld, Germany, where the issue of access to medicines was discussed for the first time in a broader civil society context (Schaaber 2006). At about the same time, Thailand and South Africa were confronted with massive pressure from the United States when they 
began to draft laws to incorporate the flexibilities the TRIPS agreement still allowed into their national legislation, with the result that Thailand quickly abandoned their plans and in South Africa, the law was immediately challenged before the High Court by the South African Pharmaceutical Manufacturers' Association (PMA) and 39 pharmaceutical companies for allegedly being unconstitutional (Sell 2002; Cameron \& Berger 2005). A number of developing countries, supported by an NGO network, made another attempt to put a resolution on the agenda of the 1998 World Health Assembly (WHA). This resolution urged WHO member states "to ensure that public health rather than commercial interests have primacy in pharmaceutical and health policies and to review their options under the Agreement on Trade Related Aspects of Intellectual Property Rights to safeguard access to essential drugs" (World Health Organization 1998) and was also met with fierce opposition from US and international pharmaceutical associations, who were supported by the United States and several European countries (Sell 2002: 504).

In 1999 the conflict gained international publicity, with Médecins Sans Frontières (MSF) joining the NGO coalition and starting its own campaign. ${ }^{3}$ MSF's specific advantage was that it already had very high public visibility in countries of the Global North. MSF also had a very high level of moral credibility, having been awarded the Nobel Peace Prize in 1999, and the organization is a large buyer of essential medicines, which it distributes in its medical aid projects in the developing world.

In the following years, several other NGOs joined the network. In their campaign for access to medicines they employed a broad arsenal of action forms. They provided expertise to developing countries' administrations and governments, lobbied northern countries to counter the position of industry lobbyists, organized meetings and conferences, published information material, and organized rallies and demonstrations in countries of both the Global North and South.

The biggest success of the mobilization was the Doha Declaration on TRIPS and Public Health at the WTO ministerial meeting in November 2001, in which the member states declared that

the TRIPS Agreement does not and should not prevent Members from taking measures to protect public health. Accordingly, while reiterating our commitment to the TRIPS Agreement, we affirm that the Agreement can and should be interpreted and implemented in a manner supportive of WTO Members' right to protect public health and, in particular, to promote access to medicines for all. (WTO 2001)

The Doha Declaration also recognized the so-called "Paragraph 6 problem," in which TRIPS allows compulsory licenses predominantly for the supply of the domestic market in Article 31(f). Negotiations to solve this problem showed a continuing deep rift between developing countries on one side and the USA and Europe on the other ('t Hoen 2009). An agreement which was reached in the WTO General Council in 2003 and reaffirmed in 2005 (WTO 2003, 2005) de facto narrows the scope of the Doha Declaration and installs a highly complex rule set that many NGOs dismiss as unworkable (Cameron \& Berger 2005; Médecins Sans Frontières 2006).

The access to medicines conflict also played out at the local level in numerous campaigns in South Africa, India, Brazil, Thailand and other countries. It was thus a true transnational and multi-level mobilization, combining lobbying, information 
campaigns, demonstrations and the creation of counter-expertise at the national and international level, within and outside organizations. During the conflict, a collective actor emerged from a network of local and transnational NGOs, engaged individuals, government officials from some countries of the Global South and other actors that brought various issues together and connected mobilizations at various levels. The mobilization connected local protests, like the demonstrations in Thailand against the US-Thailand free trade agreement and for compulsory licenses for HIV/AIDS drugs, transnational protest campaigns, like the one against pharmaceutical lobbyists in South Africa, and lobby politics at international organizations, like the work for the WTO Doha Declaration.

What was the argumentative kit holding this network together? Which frames were developed to mobilize and unite such a diverse coalition? What role did the idea of the public domain play in the discourse about access to medicines? Table 1 summarizes the frames used in core documents of the most important organizations involved in the mobilization for access to medicines.

Table 1: Frames used in the access to medicines conflict

\begin{tabular}{|l|c|c|}
\hline Frame & $\mathbf{N}$ & $\mathbf{\%}$ \\
\hline International Trade (TRIPS) & 10 & $11,6 \%$ \\
\hline Patents Restrict Access & 10 & $11,6 \%$ \\
\hline Primacy of Health & 10 & $11,6 \%$ \\
\hline Flexibilities & 8 & $9,3 \%$ \\
\hline Concrete Goals & 7 & $8,1 \%$ \\
\hline Compulsory Licenses & 5 & $5,8 \%$ \\
\hline Balance & 4 & $4,7 \%$ \\
\hline Innovation & 4 & $4,7 \%$ \\
\hline Lack of Access & 4 & $4,7 \%$ \\
\hline R\&D & 4 & $4,7 \%$ \\
\hline Generics & 3 & $3,5 \%$ \\
\hline Market Failure & 3 & $3,5 \%$ \\
\hline Parallel Imports & 3 & $3,5 \%$ \\
\hline Global Patent Pool & 2 & $2,3 \%$ \\
\hline Humanitarian Crisis & 2 & $2,3 \%$ \\
\hline Power Differences & 2 & $2,3 \%$ \\
\hline Rich Countries are not Doing Enough & 2 & $2,3 \%$ \\
\hline Other & & $2,3 \%$ \\
\hline
\end{tabular}

Not very surprisingly, the actors involved in the access to medicines mobilization identify international trade and the exclusive rights that patents confer as the core problems restricting access to medicines in the Global South, and they argue that 
health should have primacy over economic interests. The overall narrative of the access to medicines coalition can be summarized as follows (Haunss 2013: 175):

1. The problem is that millions of people have no access to essential medicines.

2. The main reason for this lack of access is that the prices for those drugs are much too high in the developing world.

3. The cause for these high prices is a market failure: Drug production is driven by profit margins and not by public health needs. Intellectual property rights aggravate the problem by prohibiting competition, and trade liberalization forces developing countries to introduce and/or strengthen these intellectual property rights that are detrimental to public health.

4. The problems can only be solved if public health concerns are given primacy over private economic interests.

5. To solve the access problem, developing countries should use compulsory licenses, promote generic competition and allow parallel imports. More generally, developing countries should make use of the TRIPS flexibilities. The transition period should be extended and a moratorium should prevent developed countries from using the dispute settlement mechanism against TRIPS violations in relation to access to medicines.

6. To address the problem more comprehensively, the TRIPS agreement should be reformed and northern countries should refrain from including TRIPS-plus clauses in bilateral or regional trade agreements.

7. Alternative mechanisms should be introduced to strengthen research and development of drugs for the needs of developing countries (Neglected Diseases Act, Medical Patent Pool), and additional financial resources should be provided to help developing countries to cope with the problem.

The first three points represent the diagnostic frame of the access to medicines coalition. Points four to seven are the prognostic frames in which actors define what to do. The motivational framing relies on the urgency of the health problem.

The framing of the access to medicines coalition is obviously not centered on the idea of the public domain. The argumentation instead focuses on the primacy of health over economic considerations, claiming that the production and distribution of medicines should primarily focus on the goal of combating serious illnesses and helping patients. The argumentation contradicts the general economic assumption that markets automatically lead to innovation and an optimal allocation of resources. Instead, the access to medicines coalition argues that markets may well lead to innovation, not necessarily in the areas where innovation would be most needed due to pressing health problems, but in areas where medical innovations are most profitable. Market processes alone are therefore not well suited to establish access to essential medicines - especially in poor countries. This contradicts the standard assumption behind the continuing expansion of intellectual property rights, that the solution for the so-called tragedy of the commons (Hardin 1968), and thus the most effective way to maximize innovation, would be the privatization of knowledge.

While the public domain is not mentioned explicitly in the framing of the access to medicines coalition, the idea nevertheless plays a role in at least two of the frames used by members of the coalition. The argumentation for compulsory licenses and 
for a global patent pool both refer to policies which would secure public access to the knowledge necessary for the production of essential medicines, at least in the Global South. And the idea for an alternative to the existing global patent system indeed found some support within the UN system, and in 2010 the "Medicines Patent Pool" was founded as a UN-backed organization. Patent holders, and in particular private pharmaceutical companies, can grant the Medicines Patent Pool (MPP) a nonexclusive license for their essential medicines. The MPP can then sublicense other firms to produce these drugs for patients in developing countries (Cox 2012).

Coming back to Boyle's suggestion that a movement against the growing propertization of knowledge should develop a mobilization frame centered around the idea of the public domain, we can see that in the largest and most transnational mobilization against the current expansion of intellectual property rights to date, the idea of the public domain plays a role but has not provided an overarching master frame for the mobilization. This may be a consequence of the idiosyncrasies of the specific case. The individual right to health has a strong normative value, and the claim that pharmaceutical profit interests would deprive patients in the Global South of this right creates an easily communicable injustice frame (Olesen 2015), well suited for winning support for the cause of the access to medicines coalition. This option is not as plausible in the case of software patents, where no human rights of vulnerable populations are touched. In the next section I will therefore analyze the framing in the second most prominent recent conflict about intellectual property rights, which surprisingly developed around an issue that - before the conflict - most commentators would not have seen as a candidate for a large-scale protest mobilization: software patents.

\section{Software patents}

The conflict over software patents in Europe - from its beginning in 1997 to its end in 2005 - involved a large number of actors and brought the former specialist issue into TV's evening news. The conflict started in June 1997 when the European Commission published a Green Paper on the Community patent and the patent system in Europe (COM 1997). It ended eight years later on 6 June 2005 when the European Parliament rejected the "Directive on the Patentability of ComputerImplemented Inventions" (COM 2002) with a majority of 648 to 14 votes. Between these dates lay a contentious mobilization, in which new collective actors emerged and entered the arena of IP politics in Europe, and which has lastingly altered the power relations in this field. The goal of the diverse coalition of actors mobilizing against the directive was effectively to make the patenting of software impossible in Europe.

The goal of the Commission was to create a sound legal basis for granting software patents in Europe. Patents for software became available in the US in the 1990s (Jaffe 2000) and have since been extensively used by the industry and forcefully criticized by academics for breaking the patent system (Jaffe \& Lerner 2004; Bessen \& Meurer 2008). The problem with software patents is that, compared to the traditional copyright protection of the program code, software patents offer an additional and much broader option to create exclusive rights. Copyrights create exclusive rights only for the specific code of a program. If another program creates 
the same functionality with different code it therefore does not violate existing copyrights. Patents, on the other hand, can create exclusive rights for a certain functionality, independent of the specific code used to realize this functionality. For two reasons it is often hard to determine whether or not a new piece of software may infringe on an existing software patent. First, given the complexity of most current software and the sheer number of patents, it is almost impossible for the average software programmer to reliably judge whether or not new software may possibly violate an existing patent. Second, this is aggravated by the tendency to formulate patent claims to be as fuzzy as possible in order to maximize the scope of a given patent.

In Europe, the European Patent Convention disallows patents for software "as such" in Article 52. But in the practice of the European Patent Office (EPO), this limitation has been interpreted very loosely so that the EPO now de facto grants software patents as long as the patent claim also mentions the hardware on which the software is run (Laub 2006). Nevertheless, because patents still have to be enforced on the national level, and because not all national courts in EU member countries follow the liberal interpretation of the EPO, the actual value of EPOgranted software patents for firms is often not clear (Ballardini 2008).

Intensive lobbying and various forms of protest accompanied the drafting of the directive and the ensuing legislative process. Proponents of software patents and of the directive proposed by the Commission were mainly national and international business associations and large ICT firms. Opponents came mainly from the Free and Open Source Software (FOSS) sector, supported by civil society organizations and small and medium sized enterprises (SME) business associations.

The conflict was characterized by dense, informal cooperation networks within each camp and a strong polarization between proponents and opponents of software patents. Opponents of software patents staged demonstrations in Brussels, Strasbourg, and in several cities in the member states, as well as virtual demonstrations on the Internet. Both sides used electronic media to lobby the members of the European Parliament and to publicize their claims and positions.

The fault lines did not run along existing cleavages of the industrial age. It was neither possible to locate the two camps along a left-right axis, nor was it a capitallabor conflict, or a conflict between industry interest and other (e.g. civil society) groups. All political parties in the European Parliament - except the Greens - were split on the issue of software patents, and while civil society organizations sided with the opponents, the majority of the oppositional actors were corporate actors themselves.

I have elsewhere (Haunss 2013; Haunss \& Kohlmorgen 2010; Leifeld \& Haunss 2012) provided a detailed discussion of the development of the conflict and an explanation of the surprising success of the comparatively resource-poor coalition of software patent opponents. These topics are not the focus of this paper. The interesting aspect here is what kind of frames the opponents used to argue and mobilize against software patents. Did they invoke the notion of the public domain in their fight against a further extension of patentability of immaterial goods? Or did they construct their mobilizing frames around other concepts?

Table 2 gives an overview of the frames used by opponents of software patents. It shows that - as in the access to medicines conflict - claims against software patents were not mainly framed by referring to the notion of a public domain. In their fight 
against software patents, the actors involved in the conflict framed their demands against software patents above all by arguing that software patents would diminish the competitiveness of SMEs, that they would impede innovation and transfer of knowledge, and that software patents would lead to monopolization in the ICT sector. They also criticized the Commission's ignorance of objections voiced by a large number of software patent opponents and by the majority of the members of the European Parliament as disrespect for democratic procedures in favor of narrow lobby interests. Together these four frames were used in more than two thirds $(67.4$ $\%)$ of the claims in which arguments were given for the opposition to software patents. ${ }^{4}$

Table 2: Frames used in the software patents conflict

\begin{tabular}{|l|c|c|}
\hline Frame & $\mathbf{N}$ & $\mathbf{\%}$ \\
\hline Competitiveness of SMEs & 42 & $23.2 \%$ \\
\hline Innovation and Transfer of Knowledge & 31 & $17.1 \%$ \\
\hline Monopolies & 25 & $13.8 \%$ \\
\hline Democratic Procedures & 24 & $13.3 \%$ \\
\hline Open Access/Open Source & 14 & $7.7 \%$ \\
\hline Economic Growth/Stability & 13 & $7.2 \%$ \\
\hline Research and Development & 10 & $5.5 \%$ \\
\hline Consumer Rights & 8 & $4.4 \%$ \\
\hline National Economy & 7 & $3.9 \%$ \\
\hline Competitiveness of the European Economy & 7 & $3.9 \%$ \\
\hline
\end{tabular}

Claims that are supported by arguments about the value of open source software and - more generally - of open access to knowledge and information are present in the opponents' framing repertoire, but they make up only about 8 percent of the frames. Thus, instead of focusing on the idea of the public domain and the principles of open source and open access which would serve to create a public domain in the area of computer software, the opponents constructed a clear storyline centered around innovation: Innovation in the IT sector would depend mainly on small firms and individual programmers whose livelihood (or business model) would be threatened by the directive. Software patents would have a negative effect on innovation in the IT sector and should therefore not be allowed in Europe. This core story was embedded in anti-monopoly and pro-democracy arguments. It contained a clear call for action ("Stop software patents!") and a strong motivational element ("Defend our livelihood!"), and thus provided a viable base for a collective identity of the activists involved in the mobilization.

\section{The role of the public domain in IP conflicts}

Similar to the constellation in the access to medicines conflict, the idea of the public domain in the software patents conflict did not provide a master frame for the 
mobilization but structured a sub-narrative about alternatives to the current system of strong and exclusive intellectual property rights. The idea of the public domain although not the term itself - is thus an important element in the actors' framing, but it does not play the role James Boyle suggested. Health, development, innovation and democracy are instead frames that actors have chosen to mobilize against the current system of extensive intellectual property rights and attempts to further strengthen the scope of protection. Even though my analysis here builds only on two cases - albeit the most prominent ones - I would argue that the low salience of the public domain in the two conflicts is not a result of the case selection but an expression of the more general conflict lines along which conflicts about the production, appropriation and distribution of knowledge have developed and most likely will develop in the future.

Boyle's narrative of intellectual property rights as a second enclosure focuses on the process of propertization: knowledge that originally is not private property is transformed into property through intellectual property rights. Against this propertization, the idea of the public domain somehow defends a natural state of knowledge, which is still free for use by everybody and therefore is not (yet) property. The idea of the public domain therefore at least partially contains a defensive element. The public domain is something that already exists or has to be recreated, and that has to be defended against encroachment by the processes of propertization, which removes ever greater parts from the public domain.

In the two cases discussed here, such a defensive argumentation is present but not dominant. Instead the focus lies in the production of knowledge. This points to the limits of the enclosure metaphor for understanding knowledge society conflicts. While intellectual property rights can restrict access to knowledge just as fences restrict access to land, knowledge - in contrast to land - can be endlessly reproduced and expanded. Therefore, not (only) the propertization of existing knowledge but the production of new knowledge is the crucial element - or at least production of new knowledge is the element that the actors involved in the conflicts focus on much more than the public domain. The rules that govern the production of knowledge determine who has access to this knowledge and under which conditions. And therefore the production of knowledge is central to the IP conflicts. I argue that both the conflict over access to medicines and the conflict over software patents directly address this issue as a conflict about the appropriate mode of innovation, i.e. a conflict about which set of social mechanisms should determine how and where new knowledge is produced.

Two perspectives stand in opposition: the industrial mode vs. a decentralized mode of innovation. The industrialized mass production of the industrial era is accompanied by industrialized mass innovation - innovation that is concentrated in large industrial units, be they large private or public research labs. The current patent system fits this centralized and industrialized mode of innovation well, and is directly challenged by the current IP conflicts. Opponents of software patents have argued that without software patents, the "real" innovators of the European hightech sector would not be the handful of large transnational corporations who make extensive use of the patent system, but the many thousands of small- and mediumsized software and technology companies, who would rather suffer than profit from patent protection in the area of software. 
In the access to medicines conflict, the industrial innovation model has been challenged from a different angle. The core criticism here was not so much that the big pharmaceutical companies would not be the "real" innovators, but that the innovation would not create the most urgently needed knowledge. Instead of producing drugs for the wealthiest patients, innovation should be geared to producing drugs against the most dangerous illnesses. Public authorities should therefore be able to intervene and redirect innovation processes and make existing drugs available according to human needs.

Both conflicts also challenge the industrial innovation model on another level. The social movement actors involved in the conflict insisted that knowledge policies and innovation processes should not be determined through market processes, but by the people and/or accountable and democratically legitimized institutions. An alternative vision of a decentralized and democratic mode of innovation emerged from these conflicts. The idea of the public domain is highly compatible with this mode of innovation but does not guide the actors' argumentative strategies.

In sum, the idea of the public domain did not provide an overarching master frame, either because actors did not realize its potential or because they were not aware of it. The public domain is simply not the metaphor that is best suited to frame a conflict about the rules for the production of knowledge. Moreover, the activists involved in the two IP conflicts discussed here do not reject the idea of intellectual property as such. They argue that the granting of property rights should require demanding social obligations for the property holders, just as material property rights in social market economies also (at least ideally) entail societal duties for the property holders.

\section{Notes}

${ }^{1}$ The newspapers from which the articles were taken are, in Germany: Süddeutsche Zeitung, die tageszeitung, Frankfurter Rundschau, Die Welt, Stuttgarter Zeitung; in the UK: Daily Mail, The Times, The Guardian, Financial Times, Western Mail, Morning Star, The Daily Telegraph, The Business, The Independent, The Observer; in France: Le Figaro, Liberation, Les Echos, Le Monde, La Tribune; and in Poland Gazeta Wyborcza, Polityka, Rzeczpospolita, Wprost.

2 India's process patents-only policy de facto followed the Swiss example. Until 1977, Switzerland only had pharmaceutical process patents and introduced product patents only after its pharmaceutical industry was well established (Boldrin \& Levine 2008: 216).

${ }^{3} \mathrm{http} / /$ www.msfaccess.org/

${ }^{4}$ In 31.4 percent of the pro- and contra statements, no explicit frame accompanied the actor's positioning against or for software patents.

\section{References}

Ballardini, R. M. (2008). Software Patents in Europe: The Technical Requirement Dilemma. Journal of Intellectual Property Law Practice 3(9): 563-575, http://dx.doi.org/10.1093/jiplp/jpn121

Bessen, J. and Meurer, M. J. (2008). Patent Failure: How Judges, Bureaucrats, and Lawyers Put Innovators at Risk. Princeton, Princeton University Press. 
Boldrin, M. and Levine, D. K. (2008). Against Intellectual Monopoly. New York, Cambridge University Press.

Boyle, J. (2003). The Second Enclosure Movement and the Construction of the Public Domain. Law and Contemporary Problems 66(1\&2): 33-74, http://dx.doi.org/10.2139/ssrn.470983

Cameron, E. and Berger, J. (2005). Patents and Public Health: Principle, Politics and Paradox. Proceedings of the British Academy 131: 331-369, http://dx.doi.org/10.5871/bacad/9780197263518.003.0012

COM. (1997). Promoting Innovation through Patents. Green Paper on the Community Patent and the Patent System in Europe. COM (1997) 314 final, Brussels, Commission of the European Communities. Retrieved November 28, 2008, from http://europa.eu/documents/comm/green_papers/pdf/ com97_314_en.pdf

COM. (2002). Proposal for a Directive of the European Parliament and of the Council on the Patentability of Computer-Implemented Inventions. COM (2002) 92, Brussels, Commission of the European Communities. Retrieved March 25, 2016, from http://eur-lex.europa.eu/legal-content/EN/TXT/ ?uri=COM:2002:0092:FIN

Cox, K. L. (2012). The Medicines Patent Pool: Promoting Access and Innovation for Life-Saving Medicines Through Voluntary Licenses. Hastings Science \& Technology Law Journal 4(2): 293-325, http://dx.doi.org/10.1037/e628452012379

Creative Commons. (2015). State of the Commons report 2015. State of the Commons. Retrieved March 7, 2016, from https://stateof.creativecommons. org/2015/cc-sotc-2015-xx12.html

Dusollier, S. (2006). The Master's Tools v. The Master's House: Creative Commons v. Copyright. Columbia Journal of Law \& the Arts 29(3): 271-293.

Gerhards, J. and Rucht, D. (1992). Mesomobilization: Organizing and Framing in Two Protest Campaigns in West Germany. American Journal of Sociology 98(3): 555-596, http://dx.doi.org/10.1086/230049

Hardin, G. (1968). The Tragedy of the Commons. Science 162(3859): 1243-1248, http://dx.doi.org/10.1126/science.162.3859.1243

Haunss, S. (2013). Conflicts in the Knowledge Society. The Contentious Politics of Intellectual Property. Cambridge, Cambridge University Press.

Haunss, S. and Kohlmorgen, L. (2008). Codebook for the Analysis of Political Claims in Conflicts on Intellectual Property Rights in Europe. Retrieved January 19, 2009, from http://www.ipgovernance.eu/publications/IPGovCodebook.pdf

Haunss, S. and Kohlmorgen, L. (2010). Conflicts about Intellectual Property Claims: The Role and Function of Collective Action Networks. Journal of European Public Policy 17(2): 242-262, http://dx.doi.org/10.1080/13501760903561534

Haunss, S. and Shadlen, K. C., eds. (2009). Politics of Intellectual Property. Contestation over the Ownership, Use, and Control of Knowledge and Information. Cheltenham, Glos, Edward Elgar Publishing.

't Hoen, E. (2009). The Global Politics of Pharmaceutical Monopoly Power. Drug Patents, Access, Innovation and the Application of the WTO Doha Declaration on TRIPS and Public Health. Diemen, AMB.

Huang, R. (2010). RQDA: R-based Qualitative Data Analysis. R package version 0.19,. Retrieved July 13, 2011, from http://rqda.r-forge.r-project.org/ 
Jaffe, A. B. (2000). The U.S. Patent System in Transition: Policy Innovation and the Innovation Process. Research Policy 29(4-5): 531-557, http://dx.doi.org/ 10.1016/s0048-7333(99)00088-8

Jaffe, A. B. and Lerner, J. (2004). Innovation and Its Discontents: How Our Broken Patent System is Endangering Innovation and Progress, and What to Do About It. Princeton, NJ, Princeton Univ. Press.

Kelle, U., Prein, G. and Bird, K. (1995). Computer-Aided Qualitative Data Analysis: Theory, Methods and Practice. Thousand Oaks, CA, Sage.

Koopmans, R. (2002). Codebook for the Analysis of Political Mobilisation and Communication in European Public Spheres. Retrieved January 19, 2009, from http://europub.wzb.eu/Data/Codebooks\%20questionnaires/D2-1-claimscodebook.pdf

Laub, C. (2006). Software Patenting: Legal Standards in Europe and the US in view of Strategic Limitations of the IP Systems. The Journal of World Intellectual Property 9(3): 344-372, http://dx.doi.org/10.1111/j.1422-2213.2006.00281.x

Leifeld, P. and Haunss, S. (2012). Political Discourse Networks and the Conflict over Software Patents in Europe. European Journal of Political Research 51(3): 382-409, http://dx.doi.org/doi: 10.1111/j.1475-6765.2011.02003.x

Médecins Sans Frontières. (2006). Neither Expeditious, nor a Solution: The WTO August 30th Decision is Unworkable. Geneva, Médecins Sans Frontières. Retrieved March 25, 2016, from https://www.msfaccess.org/sites/default/files/ MSF_assets/Access/Docs/ACCESS_briefing_NeitherExpeditiousNorSolution _WTO_ENG_2006.pdf

Olesen, T. (2015). Global Injustice Symbols and Social Movements. New York, Palgrave Macmillan.

Osborn, J. E. (2008). The Past, Present, and Future of AIDS. Journal of the American Medical Association 300(5): 581-583, http://dx.doi.org/10.1001/jama.300.5. 581

Ostrom, E. (1990). Governing the Commons: The Evolution of Institutions for Collective Action. Cambridge, Cambridge University Press.

Reis, R., Terto, V., Jr. and Pimenta, M. C., eds. (2009). Intellectual Property Rights and Access to ARV Medicines. Civil Society Resistance in the Global South. Rio de Janeiro, ABIA.

Schaaber, J. (2006). Eine kleine Chronologie. 25 Jahre BUKO Pharma-Kampagne. Bielefeld, BUKO Pharma-Kampagne.

Sell, S. K. (2002). TRIPS and the Access to Medicines Campaign. Wisconsin International Law Journal 20(3): 481-522.

Snow, D. A. and Benford, R. D. (1988). Ideology, Frame Resonance, and Participant Mobilization. In From Structure to Action. Comparing Social Movement Research Across Cultures, eds Bert Klandermans Hanspeter Kriesi and Sidney Tarrow. JAI, pp. 197-217.

Snow, D. A. and Benford, R. D. (1992). Master Frames and Cycles of Protest. In Frontiers in social movement theory, eds Adlon D. Morris and Carol McClurg Mueller. New Haven, CT, Yale University, pp. 133-155.

Titscher, S., Meyer, M., Wodak, R. and Vetter, E. (2000). Methods of Text and Discourse Analysis. London, Sage.

World Health Organization. (1998). Revised Drug Strategy (Draft). EB101.R24, World Health Organization. 
WTO. (2001). Declaration on the TRIPS Agreement and Public Health (Doha Declaration). WT/MIN(01)/DEC/2, Doha, World Trade Organization. Retrieved August 19, 2010, from http://www.wto.org/english/thewto_e/ minist_e/min01_e/mindecl_trips_e.pdf

WTO. (2003). Decision of the General Council of 30 August 2003: Implementation of paragraph 6 of the Doha Declaration on the TRIPS Agreement and public health. Retrieved August 19, 2010, from http://www.wto.org/english/tratop_e/ trips_e/implem_para6_e.htm

WTO. (2005). Amendment of the TRIPS Agreement. Retrieved August 19, 2010, from http://www.wto.org/english/tratop_e/trips_e/wtl641_e.htm 